\title{
Perancangan Backup Link Menggunakan Metode HSRP (Hot Standby Router Protocol) Dalam Penyediaan Layer-3 Redundansi
}

\author{
Tommy Elco Geraldi, Moh.Iwan Wahyuddin, Andri Aningsih \\ Fakultas Teknologi Komunikasi dan Informatika, Informatika, Universitas Nasional, Jakarta, Indonesia \\ Email: 1tommyelco@gmail.com, iwan_wyd@yahoo.com, andrianingsih@civitas.unas.ac.id
}

\begin{abstract}
Abstrak-Dengan bertambahnya pengguna jaringan internet saat ini jika hanya memiliki satu router, apabila router tersebut mengalami gangguan (down), maka internet tidak akan bisa digunakan. Berdasarkan penelitian terdahulu, penerapan metode HSRP (Hot Standby Router Protocol) dengan membuat satu active link dan satu backup link dapat mengatasi hal tersebut. Pada penelitian ini akan menggunakan metode HSRP, VTP (Vlan Trunking Protocol), InterVLAN, dan VLAN (Virtual Local Area Network) sebagai pembanding. pengujian pada penelitian ini akan menggunakan parameter packet loss dan throughput. Dari hasil pengujian yang telah dilakukan menunjukan bahwa dengan penerapan metode HSRP dapat memberikan ketersediaan jaringan dengan packet loss hanya $0,32 \%$, serta throughput sebesar $1,159 \mathrm{Mb} / \mathrm{s}(95,58 \%)$ dari penggunaan sebanyak $100 \mathrm{PC}$.
\end{abstract}

Kata Kunci: Redundancy, Link, HSRP, Metode, Failover

Abstract-With the increase of internet user today, if it only has one router, when the router experiencing a network failure, then the internet cannot be used. To overcome this problem, the HSRP (Hot Standby Router Protocol) method by creating one active link and one backup link has been applied in the previous research. In this research will be applying the HSRP, VTP (Vlan Trunking Protocol), InterVLAN, and VLAN (Virtual Local Area Network) as a comparison. The testing parameter in this research will be using packet loss and throughput. From the result of testing that has been done, it shows that by applying the HSRP method, it gives a network availability with the packet loss of only $0,32 \%$, and throughput of $1,159 \mathrm{Mb} / \mathrm{s}(95,58 \%)$ from using $100 \mathrm{PC}$.

Keywords: Redundancy, Link, HSRP, Method, Failover

\section{PENDAHULUAN}

Dengan bertambahnya pengguna jaringan internet saat ini jika hanya memiliki satu router, apabila router tersebut mengalami gangguan (down), maka internet tidak akan bisa digunakan. Untuk menanggulangi permasalahan yang ada, maka dapat diterapkan konsep metode HSRP (Hot Standby Router Protocol), yaitu suatu metode dimana terdapat satu active link yang berguna sebagai link utama untuk melanjutkan packet dan satu standby link yang berguna sebagai backup link untuk melanjutkan packet ketika link utama mengalami gangguan dan apabila link utama kembali normal, maka backup link tersebut akan kembali menjadi standby (tidak aktif)[1]-[2].

Sebelumnya dilakukan penelitian oleh Ala Mohamed Ali Mohamed dkk menguji metode HSRP tanpa mengkombinasikan dengan penambahan metode VTP (Vlan Trunking Protocol), InterVLAN, dan VLAN (Virtual Local Area Network) adalah pilihan terbaik dalam membuat layer-3 redundansi[3]. Penelitian yang dilakukan oleh Wisnu Purwanto dkk tanpa mengkombinasikan dengan penambahan metode VTP (Vlan Trunking Protocol), InterVLAN, dan VLAN (Virtual Local Area Network) mengatakan bahwa dengan penerapan metode HSRP dapat memberikan redundansi pada layer-3 yang handal[4].

Berdasarkan penelitian tersebut, pada penelitian kali ini akan menerapkan metode HSRP (Hot Standby Router Protocol) dikombinasikan penambahan metode VLAN (Virtual Local Area Network), InterVLAN, dan VTP (Vlan Trunking Protocol) yang diharapkan bisa mendapatkan hasil lebih baik.

\section{METODE PENELITIAN}

\subsection{HSRP (Hot Standby Router Protocol)}

HSRP merupakan suatu metode yang diterapakan pada perangkat jaringan Cisco, dimana konsep yang digunakan adalah dengan membuat satu virtual gateway IP address pada dua perangkat, sehingga dua perangkat tersebut memiliki virtual gateway yang sama satu dengan yang lainnya[5]. HSRP memiliki satu active link dan satu standby link, dimana active link adalah interface utama yang bekerja untuk melanjutkan packet yang keluar dan masuk, sedangkan standby link adalah interface kedua (backup link) yang akan langsung bekerja secara langsung jika jalur utama mengalami link down[6]-[7].

\subsection{InterVLAN Routing}

InterVLAN Routing adalah metode untuk melakukan routing antar VLAN atau untuk meneruskan traffic antar VLAN yang telah didaftarkan agar tetap bisa saling terhubung, meskipun memiliki VLAN yang berbeda atau network yang tidak berada dalam satu segmen yang sama.

\subsection{VTP (Vlan Trunking Protocol)}


VLAN digunakan untuk membuat beberapa segmen network berbeda, namun tetap bisa saling terhubung satu sama lainnya. VTP digunakan untuk metode trunking milik Cisco yang berfungsi untuk menyederhanakan pembuatan VLAN pada switch, sehingga proses pembuatan VLAN tidak harus dilakukan pada semua switch.

Semua konfigurasi akan dilakukan melalui CLI (Command Line Interface) menggunakan aplikasi terminal SecureCRT pada perangkat Cisco yang akan disimulasikan menggunakan aplikasi GNS3 (Graphical Network Simulator 3). SecureCRT adalah aplikasi terminal emulator yang berguna untuk melakukan SSH, TELNET, dan juga mengkonfigurasi perangkat jaringan. GNS3 (Graphical Network Simulator 3) merupakan aplikasi simulasi jaringan komputer berbasis GUI yang bersifat open source. GNS3 dapat mensimulasikan jaringan yang kompleks dan memiliiki berbagai fitur yang dapat digunakan untuk keperluan seperti design, testing, training, dan juga penelitian menggunakan Cisco IOS (Cisco Internetwork Operating System) dari router dan switch asli.

\subsection{Kerangka Penelitian}

Penelitian ini menerapkan metode HSRP (Hot Standby Router Protocol) dalam perancangan jaringan yang dibuat dan disimulasikan menggunakan aplikasi GNS-3 (Graphical Network Simulator-3)

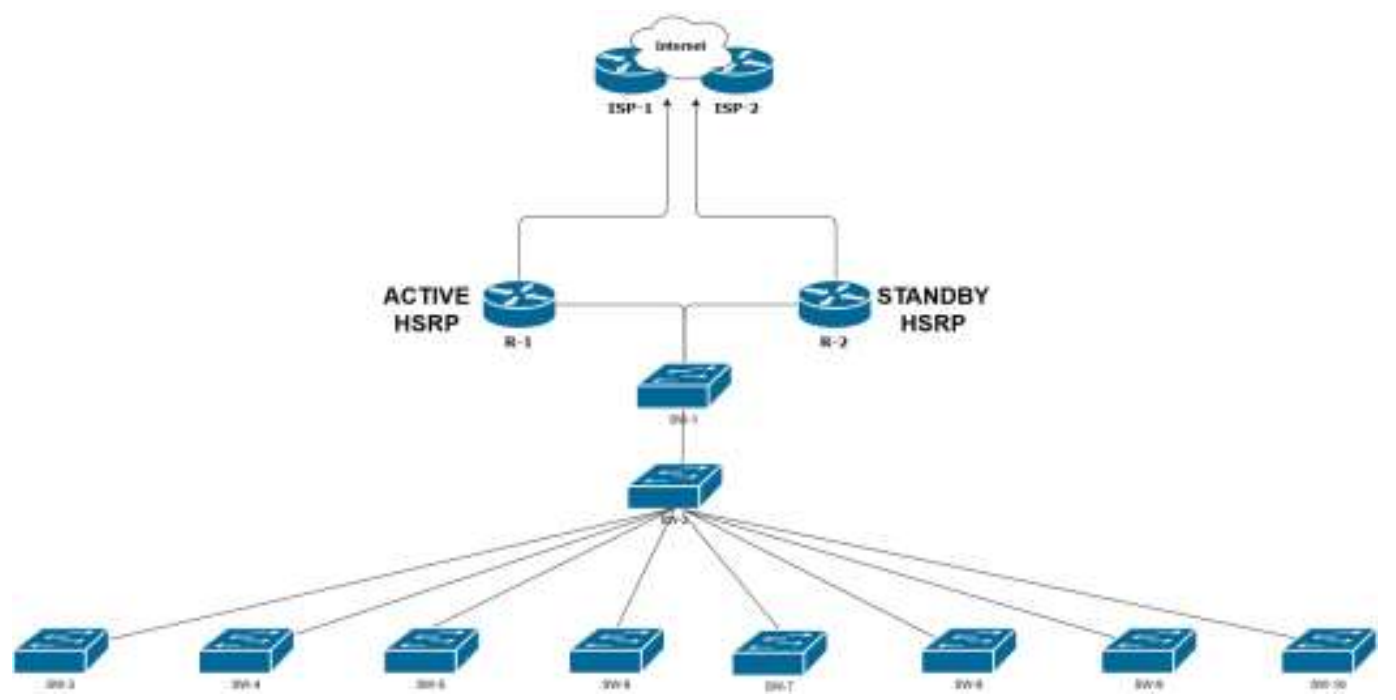

Gambar 1. Desain Topologi

Gambar 1 merupakan desain topologi yang akan diterapkan dalam proses perancangan jaringan pada penelitian ini, dengan mengimplementasikan metode HSRP (Hot Standby Router Protocol), sehingga terdapat backup link pada jaringan layer-3 network.

Bagan alur (Flowchart) proses perancangan jaringan yang akan menerapkan metode Hot Standby Router Protocol dimulai dari proses studi pustaka sampai dengan analisa QOS dapat dilihat pada gambar dibawah ini.

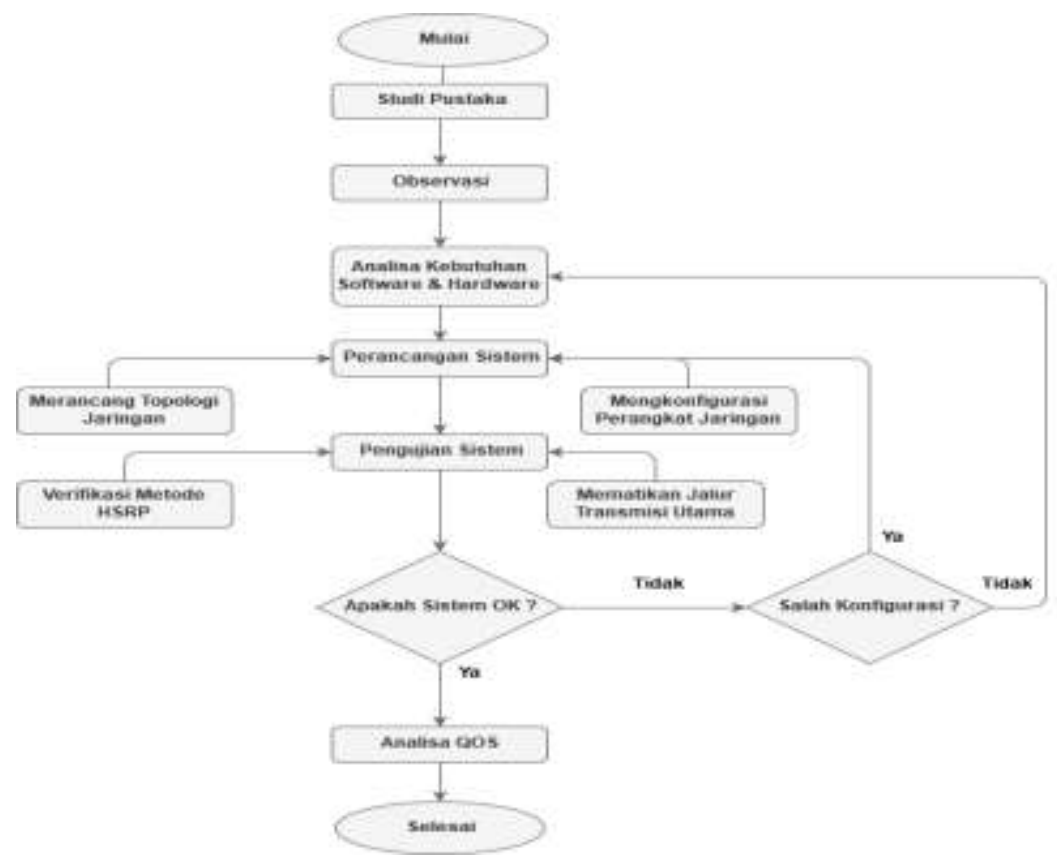

Gambar 2. Flowchart Perancangan Jaringan Metode HSRP 
a. Berdasarkan flowchart yang telah dibuat dapat dijelaskan secara ringkas sebagai berikut :

b. Mencari jurnal sebagai bahan referensi penelitian.

c. Melakukan pengamatan terhadap object yang akan diteliti.

d. Meneliti kebutuhan software dan hardware yang akan digunakan dalam melakukan penelitian ini.

e. Merancang topologi jaringan serta melakukan konfigurasi pada setiap perangkat jaringan.

f. Melakukan pengujian terhadap sistem, apakah sistem hasil rancangan OK. Jika terdapat kesalahan pada konfigurasi jaringan, maka akan kembali ke point d. Jika bukan dari konfigurasi maka kembali pada point $\mathrm{c}$.

g. Menganalisa QOS pada jaringan yang telah dibuat dan berjalan dengan benar

\subsection{Kebutuhan Hardware dan Software}

Dalam melakukan penelitian ini dibutuhkan alat pendukung perangkat keras dan lunak, diantaranya adalah :

\subsubsection{Spesifikasi Perangkat Keras}

Tabel dibawah ini adalah spesifikasi perangkat keras yang digunakan dalam melakukan penelitian ini.

Tabel 1. Spesifikasi Perangkat Keras

\begin{tabular}{ll}
\hline Perangkat & Spesifikasi Perangkat \\
\hline Processor & Intel i5-8250u 1.60GHz $-3.40 \mathrm{GHz}$ \\
Memory & DDR4 16GB \\
Storage & SSD 512GB + Harddisk 1TB \\
VGA & Nvidia Geforce MX150 \\
Monitor & LG-MK600 24 Inch \\
OS & Windows 10 Pro \\
\hline
\end{tabular}

\subsubsection{Software}

Dibawah ini adalah software yang digunakan dalam melakukan penelitian ini.

a. GNS3, Software ini digunakan untuk melakukan simulasi jaringan yang telah dirancang.

b. VMware, VMware digunakan sebagai server untuk aplikasi GNS3, yang gunanya untuk memperingan kinerja memori.

c. SecureCRT, SecureCRT ini digunakan sebagai terminal cli untuk mengkonfigurasi perangkat jaringan seperti router dan switch.

d. Wireshark, Software Wireshark digunakan untuk membantu melakukan analisa pada penelitian ini.

e. IOSv, IOSv digunakan sebagai virtual OS pada router dan switch.

\section{HASIL DAN PEMBAHASAN}

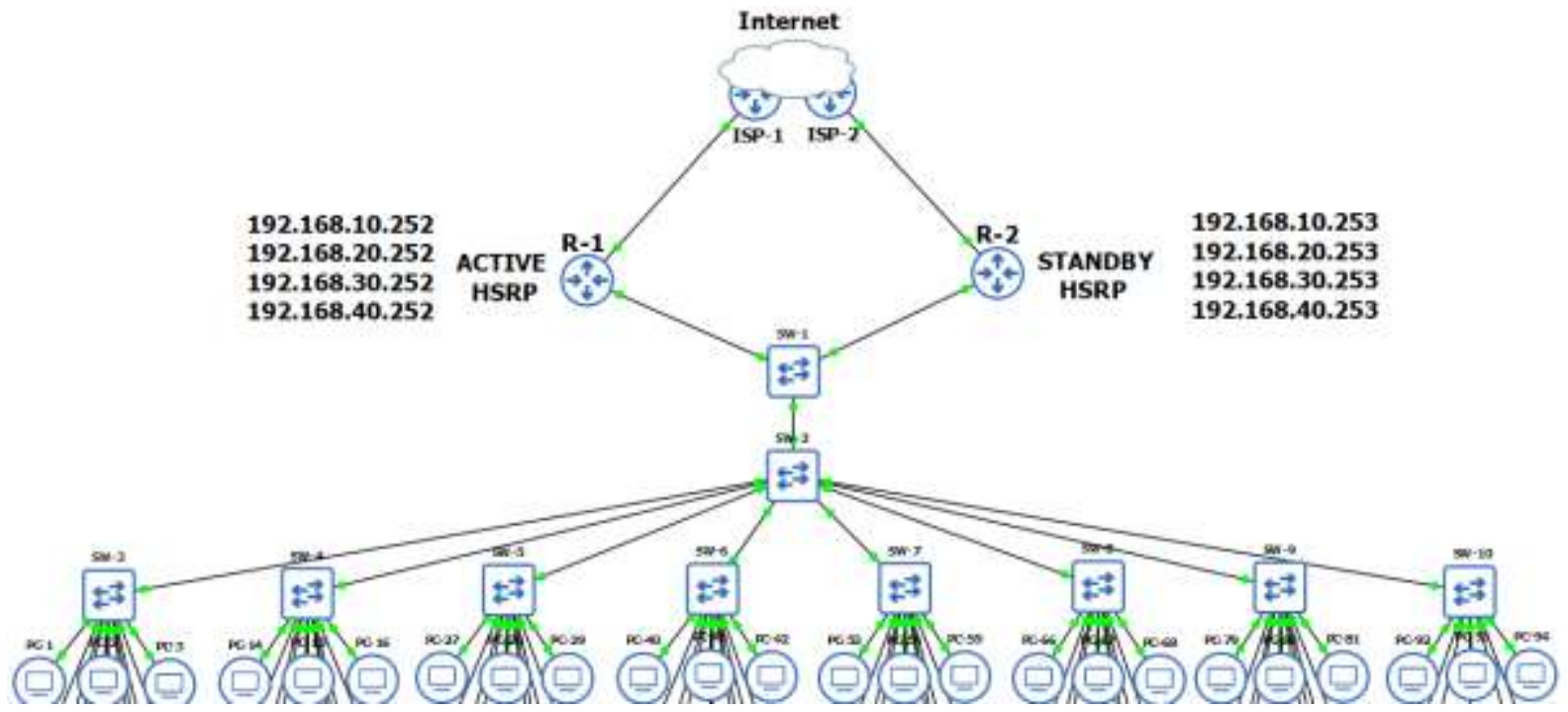

Gambar 3. Topologi Jaringan Metode HSRP

Topologi pada Gambar 3. Pada saat PC mengakses internet, user tidak perlu khawatir akan terjadi kegagalan dalam mengirim packet jika terjadi link down pada jalur transmisi kabel utama, karena secara otomatis router akan mengunakan backup link. Dalam topologi ini, router telah dikonfigurasi metode Hot Standby Router Protocol, sehingga dengan adanya metode HSRP maka akan memiliki backup link, karena fungsi dari HSRP adalah untuk membuat redundansi pada layer 3 . 
Volume 4, Nomor 1, Januari 2020, Page 201-207

ISSN 2614-5278 (media cetak), ISSN 2548-8368 (media online)

Available Online at https://ejurnal.stmik-budidarma.ac.id/index.php/mib DOI 10.30865/mib.v4i1.1873

\subsection{Pengujian Metode Hot Standby Router Protocol}

Pada tahap ini, akan dilakukan ping dari PC-1 ke IP 8.8.8.8 (google.com) yang bertujuan untuk memastikan bahwa pengiriman packet berjalan dengan baik, trace route yang bertujuan untuk melihat hop yang dilalui dari PC-1 ke alamat IP 8.8.8.8 (google.com) guna memastikan apakah proses failover berjalan dengan benar, serta menggunakan command show standby pada terminal SecureCRT guna mengetahui status dari HSRP, lalu menguji dengan cara membuat link down dengan sengaja pada jalur kabel transmisi utama guna mengetahui apakah perpindahan link dari jalur transmisi utama ke backup link berlangsung secara otomatis. Hal ini penting untuk menjamin ketersediaan backup link ke jaringan secara utuh tanpa perlu adanya pemindahan secara manual yang dapat meningkatkan down time. Pada pengujian ini akan secara bertahap menggunakan semua PC yang ada pada topologi jaringan diatas, namun sebagai contoh untuk mengetahui alur kerja dari metode HSRP, pada gambar dibawah ini akan diwakili menggunakan PC-1 sebagai contoh.

\subsubsection{Pemutusan Link dan Proses Failover}

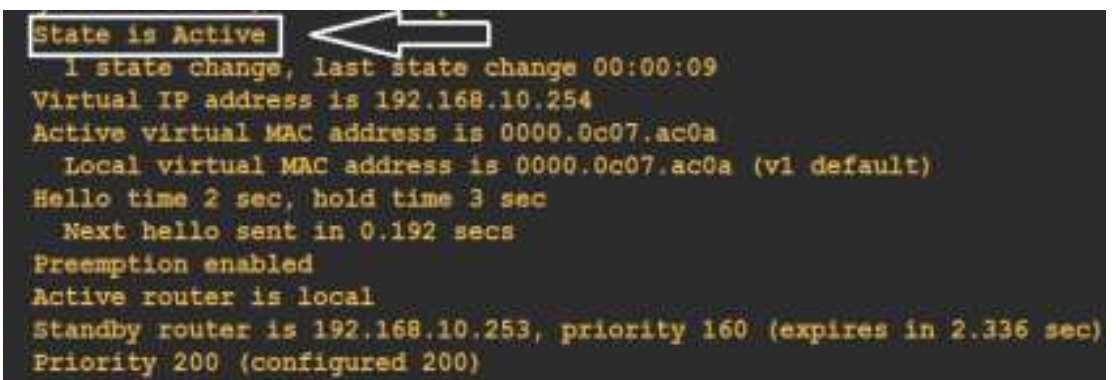

Gambar 4. Status HSRP Pada R-1 Sebelum Terjadi Failover

Pada Gambar 4, bisa dilihat bahwa status interface pada R-1 masih dalam keadaan State is Active, yang berarti bahwa belum terjadi failover, sehingga packet yang akan dikirim keluar akan tetap melalui link utama, yaitu R-1 seperti yang dapat dilihat pada Gambar 3.

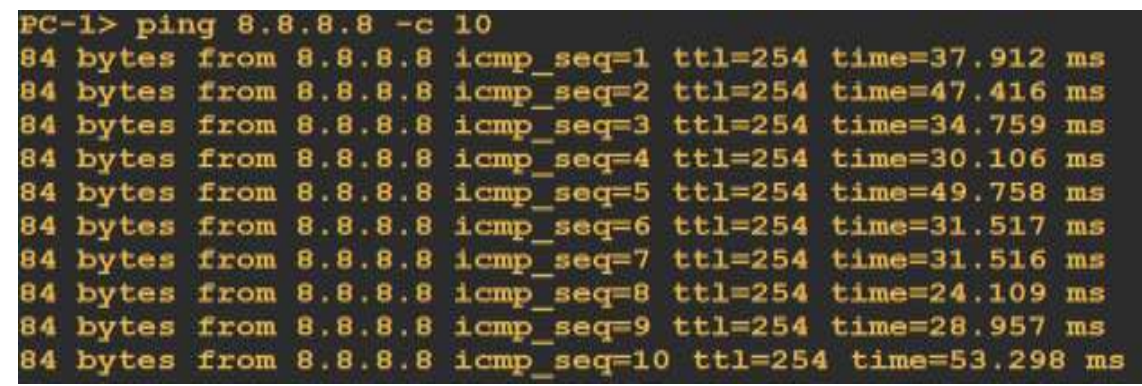

Gambar 5. Kondisi PC-1 Sebelum Terjadi Failover

Pada Gambar 5 dilakukan ping dari PC-1 ke alamat IP 8.8.8.8 (google.com) dengan sukses melalui jalur kabel transmisi utama sebelum terjadinya failover, yaitu R-1.

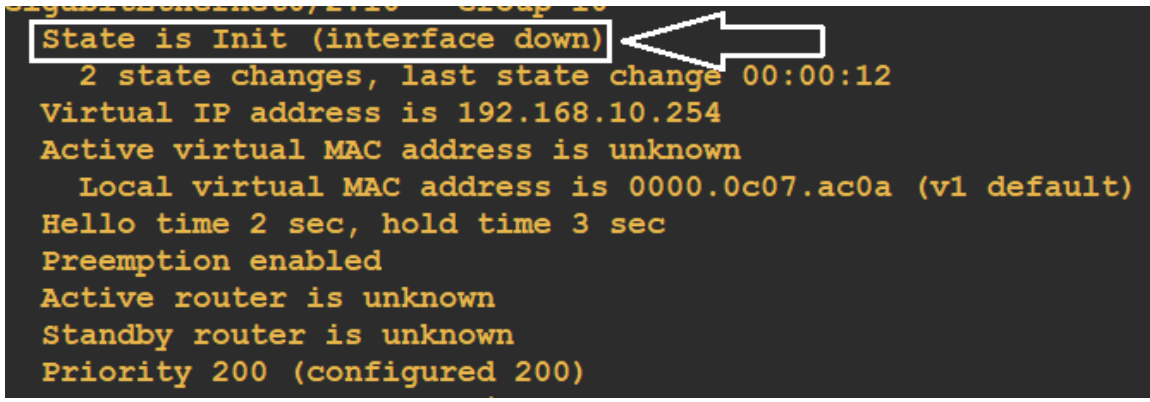

Gambar 6. Status HSRP Pada R-1 Setelah Terjadi Failover

Pada Gambar 6, terlihat bahwa setelah dengan sengaja dilakukan link down pada jalur transmisi utama, status interface telah berubah dari active menjadi init (Tidak aktif lagi), dimana itu berarti proses backup link telah terjadi, sehingga sekarang jika ada packet yang akan dikirim keluar, maka packet tersebut akan melewati backup link yang berada pada R-2 seperti yang dapat dilihat pada gambar 3. 


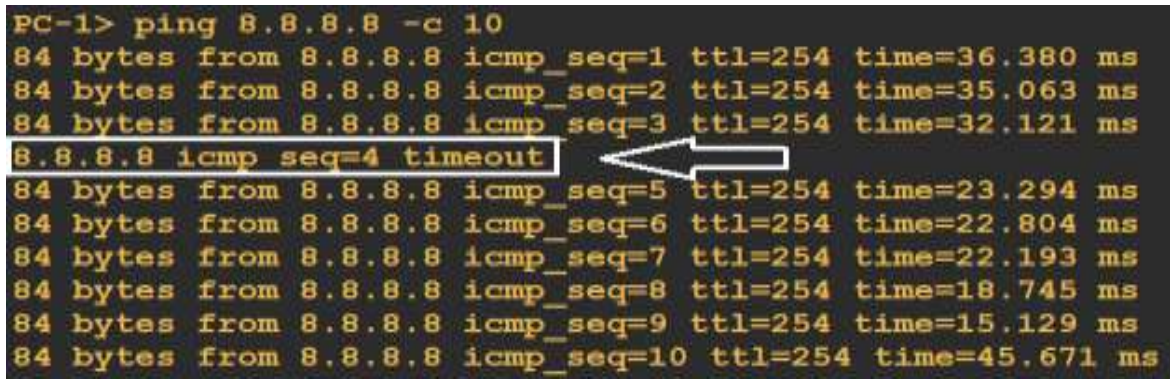

Gambar 7. Kondisi PC-1 Saat Proses Failover ke Backup Link

Gambar 7 menunjukan bahwa pada saat pengiriman packet dari PC-1 ke IP 8.8.8.8 (google.com) terjadi link down yang dilakukan dengan sengaja, sehingga pada gambar 7 terdapat 1 packet yang tidak dapat terkirim. Pada gambar 7 terbukti bahwa failover dari link utama ke backup link berhasil dilakukan, sehingga proses pengiriman packet terus berlanjut melalui backup link, yaitu melalui R-2 seperti yang dapat dilihat pada gambar 3 .

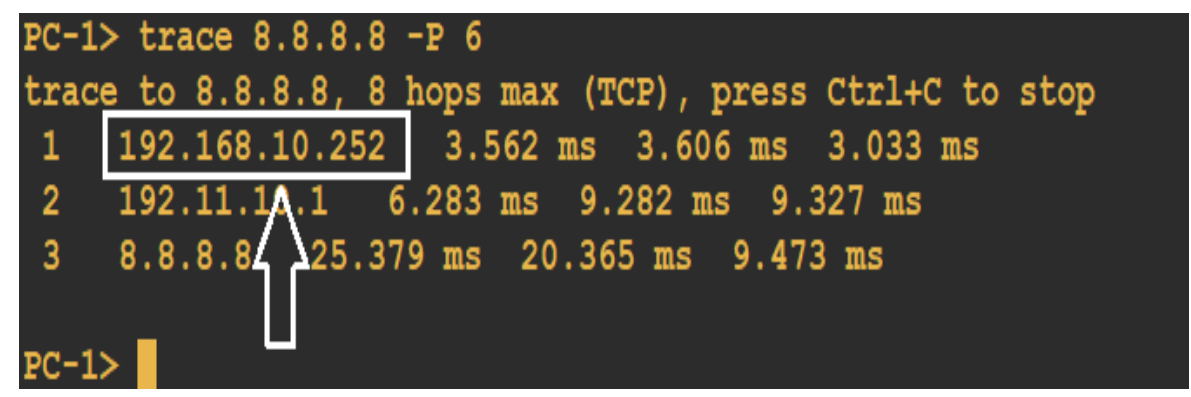

Gambar 8. Trace Route Sebelum Failover

Pada Gambar 8 dilakukan trace route dari PC-1 ke alamat IP 8.8.8.8 (google.com) menggunakan link utama, terbukti dengan output alamat IP 192.168.10.252 pada gambar diatas, yaitu alamat IP address link utama pada R1 seperti yang dapat dilihat pada gambar 3 .

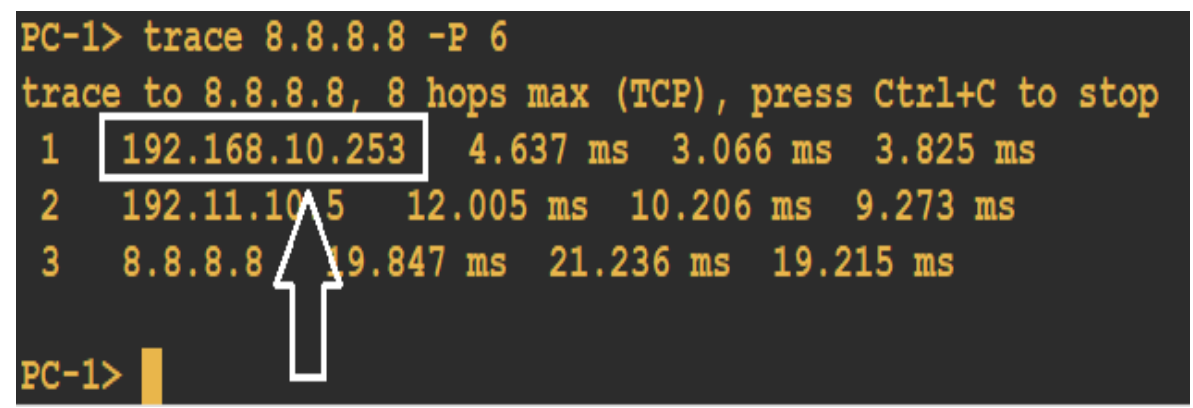

Gambar 9. Trace Route Setelah Failover

Pada Gambar 9 setelah proses failover dilakukan trace route dari PC-1 ke alamat IP 8.8.8.8 (google.com) menggunakan backup link, terbukti pada gambar diatas memiliki output dengan alamat ip 192.168.10.253, dimana itu adalah IP address milik backup link pada R-2 seperti yang terlihat pada gambar 3.

\subsection{Parameter QOS (Quality Of Service)}

Parameter pengujian yang dilakukan untuk melihat kinerja dari penerapan metode HSRP akan berfokus pada dua parameter, yaitu packet loss dan throughput.

\subsubsection{Packet Loss}

Packet Loss merupakan suatu parameter dalam menentukan jumlah packet yang tidak terkirim atau hilang. Penyebab packet loss bisa dikarenakan terjadinya gangguan pada jalur transmisi kabel.

Tabel 2. Standarisasi Packet Loss Berdasarkan ITU-T

\begin{tabular}{ll}
\hline Kategori Degradasi & Packet Loss $(\%)$ \\
\hline Sangat Bagus & $0-2$ \\
Bagus & $3-14$ \\
Sedang & $15-24$ \\
Buruk & $>25$ \\
\hline
\end{tabular}


ITU-T (International Telecommunication Union Telecommunication) merupakan sebuah badan internasional yang merancang standar tingkat dunia untuk peralatan dan sistem telekomunikasi. Pada penelitian ini, peneliti menggunakan ITU-T sebagai acuan hasil packet loss yang telah diteliti.

\subsubsection{Throughput}

Throughput adalah suatu parameter kemampuan dari suatu jaringan dalam melakukan pengiriman data.

Tabel 3. Standarisasi Throughput Berdasarkan TIPHON

\begin{tabular}{ll}
\hline Kategori Throughput & Nilai $(\%)$ \\
\hline Sangat Bagus & $76-100$ \\
Bagus & $51-75$ \\
Sedang & $26-50$ \\
Buruk & $<25$ \\
\hline
\end{tabular}

TIPHON (Telecommunications and Internet Protocol Harmonization Over Networks) adalah sebuah badan internasional yang merancang standar QOS (Quality Of Service). Pada penelitian ini, TIPHON digunakan oleh peneliti sebagai acuan hasil throughput yang telah diteliti.

\subsection{Grafik Hasil Pengujian Packet Loss dan Throughput}

Penggujian packet loss akan dilakukan sebanyak 4 kali, yang mana pengujian pertama menggunakan 70 PC, pengujian kedua dilakukan menggunakan $80 \mathrm{PC}$, pengujian ketiga menggunakan $90 \mathrm{PC}$, dan pengujian ke empat menggunakan $100 \mathrm{PC}$, sedangkan pengujian throughput dilakukan dengan cara memberikan beban traffic sebesar $1,2 \mathrm{Mb}$ pada jaringan, lalu pada waktu tertentu koneksi pada jalur transmisi utama yang berada pada R-1 seperti yang dapat dilihat pada Gambar 3 diputus secara sengaja.

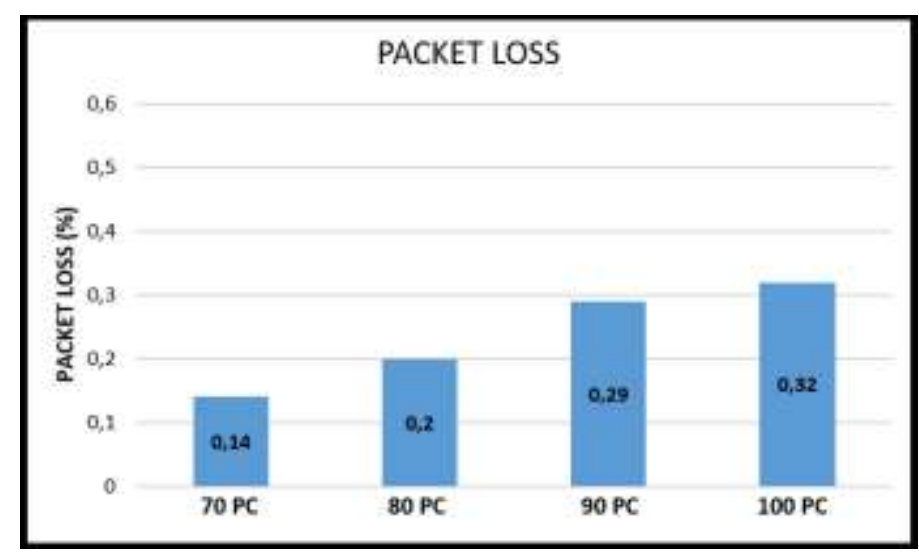

Gambar 10. Grafik Hasil Pengujian Packet Loss Metode HSRP

Dari Gambar 10 dapat dilihat bahwa hasil pengujian packet loss menggunakan 70 PC, 80 PC, 90 PC, dan 100 PC tidak ada yang melebihi $1 \%$. Jika merunjuk pada ITU-T, maka hasil pengujian packet loss yang telah dilakukan termasuk kedalam kategori yang Sangat Bagus, karena dari hasil pengujian packet loss yang telah dilakukan terdapat hasil terkecil dari pengujian $70 \mathrm{PC}$ sebesar $0,14 \%$ dan hasil terbesar dari pengujian $100 \mathrm{PC}$ sebesar $0,32 \%$, sehingga dengan penerapan metode HSRP dapat disimpulkan dapat meningkatkan ketersediaan jaringan yang terjamin

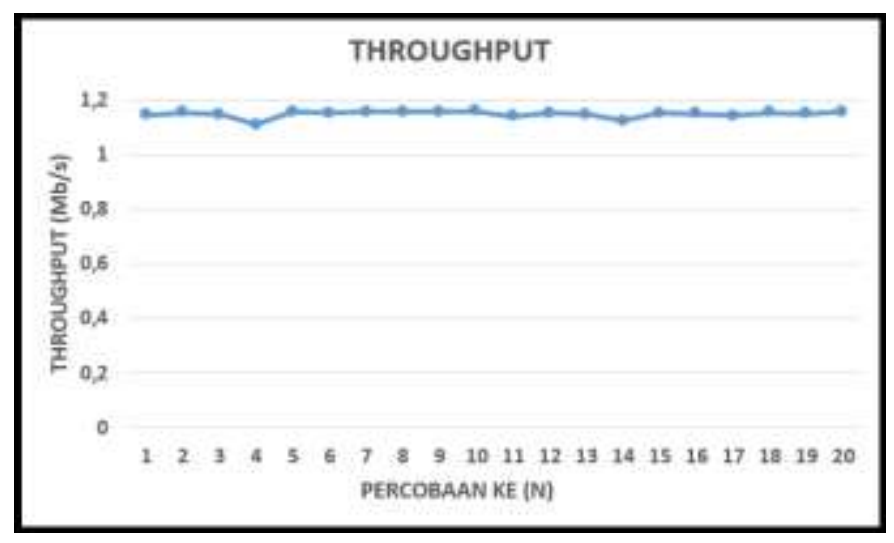

Gambar 11. Grafik Hasil Pengujian Throughput Metode HSRP

Tommy Elco Geraldi, Copyright (C) 2020, MIB, Page 206 
Pada Gambar 11 terlihat bahwa saat memberikan traffic sebesar 1,2Mb pada jaringan dan kemudian dilakukan pemutusan sescara sengaja terdapat throughput terendah sebesar $1,108 \mathrm{Mb} / \mathrm{s}(92,33 \%)$, throughput tertinggi sebesar 1,159Mb/s (96,58\%), serta jika dirata-ratakan, maka throughput dari penerapan metode HSRP adalah sebesar 1,147Mb/s (95,58\%). Jika dilihat pada Tabel 3 yang merunjuk pada TIPHON, maka hasil pengujian throughput termasuk kedalam kategori Sangat Bagus.

\section{KESIMPULAN}

Berdasarkan hasil pengujian dengan memanfaatkan metode HSRP, ketersediaan jaringan pada layer 3 network terjamin karena adanya active link dan backup link dari penerapan metode Hot Standby Router Protocol, terbukti dari pengujian yang telah dilakukan dengan penggunaan sebanyak $100 \mathrm{PC}$ hanya terdapat $0,32 \%$ packet loss, sedangkan untuk throughput terdapat hasil yang berbeda-beda ketika dilakukan link down, namun throughput tetap terjaga karena adanya penerapan metode HSRP. Hal ini berguna jika HSRP diterapkan pada perusahaan yang memiliki banyak user dan tidak ingin terjadi link down pada layer 3 ketika terjadi masalah pada jalur transmisi kabel utama, karena dengan menggunakana metode HSRP ini, ketika jalur transmisi utama mengalami link down, maka secara otomatis akan langsung menggunakan backup link, sehingga ketersediaannya terjamin.

\section{REFERENCES}

[1] C. V. Ravikumar, Y. M. Srikanth, P. Sairam, M. Sundeep, K. P. Bagadi, and V. Annepu, "Performance analysis of HSRP in provisioning layer-3 gateway redundancy for corporate networks," Indian J. Sci. Technol., vol. 9, no. 20, pp. 2-6, 2016.

[2] A. K. Singh and A. Kothari, "HSRP (Hot Stand by Routing Protocol) reliability issues over the Internet service provider's network," Orient. J. Comput. Sci. Technol., vol. 4, no. 2, 2011.

[3] A. M. A. Mohamed, J. N. P. Soon, W. S. Wan, P. K. Yuen, and L. E. Heng, "Hot Standby Router Protocol for a Private University in Malaysia," Int. J. Sci. Eng. Technol., vol. 4, no. 3, pp. 172-174, 2015.

[4] W. Purwanto and S. Risnanto, "Implementasi Metode HSRP Pada Bank Jawa Barat dan Banten Kantor Wilayah I dan KCP Simpang Dago," vol. 3, no. 1, 2018.

[5] W. H. Pamungkas and E. Prayitno, "Perancangan Jaringan Redundancy Link Menggunakan Konsep HSRP dan Etherchannel (Studi Kasus PT. Telkom Area Palangkaraya)," Metik, vol. 2, no. 1, pp. 75-82, 2018.

[6] B. I. D. Kumar and G. Vasanth, "Performance Evaluation of HSRP based reliable Multihomed Network for two Different Applications," vol. 6, no. 8, pp. 92-99, 2017.

[7] P. Kaur, H. Kaur, and J. Kaur, "Hot Standby Routing Protocol ( HSRP )," vol. 3, no. 1, pp. 2110-2112, 2017. 